International Journal of Business Management and Economic Review

Vol. 4, No. 04; 2021

ISSN: 2581-4664

\title{
THE EFFECT OF ENDORSER CREDIBILITY ON BRAND EQUITY OF WARDAH PRODUCTS IN BANDA ACEH AND SABANG WITH BRAND CREDIBILITY AS A MEDIATION: DOES THE GEOGRAPHIC CAN BE AS A MODERATION?
}

\author{
*Diana Wildani, Syafruddin Chan and Sorayanti Utami \\ Management Department, Universitas Syiah Kuala, Indonesia \\ http://doi.org/10.35409/IJBMER.2021.3280
}

\begin{abstract}
This study aims to analyze the effect of endorser's credibility on Wardah product brand equity in Banda Aceh and Sabang with credibility as a mediating variable and geography as a moderating variable. The population taken in this study was the people of Banda Aceh and Sabang, as the users of Wardah products. The sample used was purposive sampling with the number of respondents in this study were 200 people. Because in this study using the geographic variable as moderating variable, the number of a sample taken was divided into two, namely 100 respondents for the Banda Aceh area and 100 respondents for the Sabang area. The analysis technique used in this research was quantitative analysis using the SEM (Structural Equation Modeling). The research model was tested into 3 models, namely the combined model between the Banda Aceh and Sabang areas, the Banda Aceh model, and the Sabang model. The results show that the 3 models for direct and mediation hypothesis testing produced the same significant results, namely endorser credibility significantly affects brand credibility, endorser credibility significantly affects brand equity, brand credibility significantly affects brand equity, and brand credibility significantly mediates the effect of endorser credibility on brand equity. What distinguishes it is the coefficient of value, which can be used as a measure of comparison between the combined model, the Banda Aceh model, and the Sabang model, which can be used as a comparative analysis. For the moderation test in the combined model, it reveals that Geographic does not significantly moderate the influences in the research model, which means the presence of this variable does not affect the research model. These findings prove that the designed model can be used to increase Wardah Product's brand equity for Banda Aceh and Sabang cities, without taking geographic variable into account. This means that strategies to increase brand equity for the Banda Aceh and Sabang geographic areas will tend to be the same. The findings also prove that Banda Aceh and Sabang have their respective advantages and achievements in treating each variable in this research model so that they can exemplify each other and combine their future strategies.
\end{abstract}

Keyword: Endorser Celebrity, Brand Credibility, Brand Equity, Geographic.

\section{INTRODUCTION}

In today's business world, competition in the field of marketing is getting tougher. Competition is becoming tighter Competition is increasing. Therefore, companies are required to 


\section{International Journal of Business Management and Economic Review}

Vol. 4, No. 04; 2021

ISSN: 2581-4664

carry out the right marketing strategies and can win the competition and be able to increase the market. One of the ways companies maintain or capture the market is by choosing an appropriate endorser to choose to facilitate the contents of the product. An endorser who has a great appeal, expertise to convey product contents and trust, so that consumers trust the information conveyed by endorsers and consumers can also trust the product.

The emergence of Wardah cosmetics can provide additional quality cosmetic choices for cosmetic consumers in Indonesia. Wardah is a cosmetic brand produced by PT. Paragon Technology and Innovation in Indonesia, and Wardah also has entered international marketing such as in neighboring countries such as Malaysia. This is of course related to the role of using hijab celebrities who were the initial segmentation of this product, namely halal cosmetic products.

Wardah ranks at the top in several types of cosmetic product sales in the last three years, namely 2016, 2017, and 2018 (https://www.topbrand-award.com/ ). In 2016, Wardah occupied first place in the list of top brands measured using the Top Brand Index (TBI) in several types of cosmetic products such as the type of Lipstick. 22.3\%, Lip Gloss 13.7\%, Blush 23.0\%, Foundation 26.9\% and Compact Face Powder 25.0\%. All types of cosmetics mentioned earlier were ranked first in the selection of top brands in 2016, so it can be concluded that Wardah has a large demand for sales in 2016. In 2017, several types of Wardah cosmetics still occupied top brands and even increased from the previous year. For this type of lipstick, it increased from $22.3 \%$ to $25.0 \%$. For Lip Gloss, it also increased from $13.7 \%$ to $23.1 \%$. Then for the compact face powder also increased from $25.0 \%$ to $26.0 \%$. For Blush On, there was a slight decrease in 2017, which was down from $23.0 \%$ to $21.3 \%$. Then also the decline was the Foundation, which fell from $26.9 \%$ to $23.1 \%$. Despite having two types of cosmetics that have decreased, Wardah still occupied the first position in the 2017 top brand. In 2017, Wardah was even able to add types of products to the Top Brands, namely Eyeliner with TBI 19.2\%, BB Cream 26,\% and Loose Powder by $17.0 \%$. In 2018 TBI Lipstick increased from $25.0 \%$ to $36.2 \%$. For Lip Gloss, it also increased from $23.1 \%$ to $31.8 \%$. Then for the Blush On also increased from $21.3 \%$ to $29.7 \%$. For the Foundation product, it increased from $23.1 \%$ to $28.0 \%$. And the Powder Face Compact also increased from $26.0 \%$ to $35.5 \%$. Likewise for BB Cream, which increased from $26.0 \%$ to $41.4 \%$. For Loose Powder, it increased from $17.0 \%$ to $21.8 \%$ and for Eyeliner in 2018 it decreased from $19.2 \%$ to $16.4 \%$.

So from the explanation, we can see that in several categories of cosmetic products, Wardah has always placed its products in the top brand category for 3 consecutive years, such as Lipstick, Lip Gloss, Blash On, and Foundation, so we can conclude that Wardah has implemented its brand equity strategy well. But, In the case of Wardah products in the city of Banda Aceh and Sabang, Indonesia, their equity problem is not proportional to the national level brand equity. This was evidenced by the author's preliminary survey of 30 respondents to see how strong brand equity is among cosmetic product users in the cities of Banda Aceh and Sabang.

\section{LITERATURE AND HYPOTHESIS Brand Equity}

Brand equity is a positive effect arising from the knowledge of brand names and customer responses to a product or service (Kotler \& Keller, 2018). the company will more easily get a 
Vol. 4, No. 04; 2021

ISSN: 2581-4664

positive value from consumers. Brand Equity is an added value that can be given to a product or service. Brand Equity is a reflection of the way consumers feel, think and act on their relationship with a brand, price, market share, and profitability that they can provide to the company (Kotler \& Keller, 2009).Dimensions of Brand Equity according to (Chen \& Chang, 2008) are divided into 3 dimensions namely; (1) Brand Awareness (2) Brand loyalty (3) Perceived Quality.

\section{Brand Credibility}

Brand Credibility is trust in the information of a product that is in a brand, which is needed by consumers to understand or understand that the brand has a willingness, that is trust and possessing such expertise to continuously be able to deliver what has been promised by the brand. (Tulin Erdem \& Swait, 2004) in (Sheeraz, Iqbal, \& Ahmad, 2012).Dimensions of Brand credibility According to (Tülin Erdem, Swait, \& Louviere, 2002) in (Baek \& King, 2011) define Brand Credibility has two dimensions, Expertise, and Trustworthiness

\section{Endorser credibility}

One way to be able to attract the attention of consumers and be able to attract consumer buying interest is to create creative and innovative advertisements. To be able to produce creative advertising that is by using the support of a credible endorser celebrity to convey the message contained in the product. Celebrity endorsement is the use of an artist, athlete, entertainer, or public figure who is widely recognized by the public in his success in their respective fields (Shimp, 2013).

Endorsement is a communication channel in marketing in which a celebrity acts as a representation of a brand and emphasizes that the represented brand represents its popularity, personality, and status in society. In the market of a brand at the local or international level, using endorser celebrity is a way to differentiate a brand from other brands (Roll, 2006) in (Mukherjee, 2009). The dimensions of Endorser Credibility are (1) Attractiveness (2) Trustworthiness.

\section{Research Model and Hypothesis}

From the discussion above, the research model that can be formulated is as follows. 


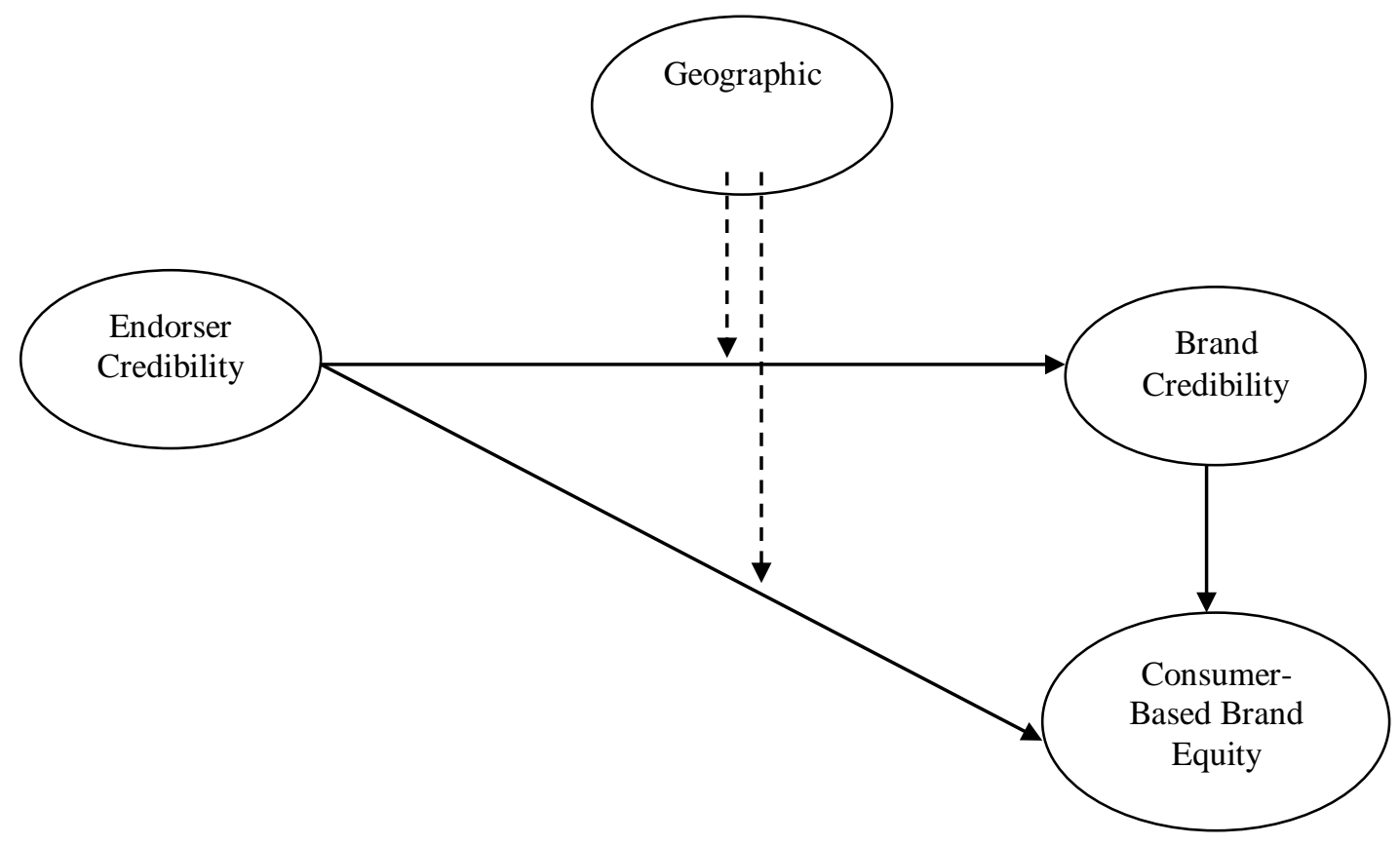

Figure 1. Research Model

While the research hypothesis can be stated as follows.

Hypothesis 1 : endorser credibility significantly affects brand credibility

Hypothesis 2 : endorser credibility significantly affects brand equity

Hypothesis 3 : brand credibility significantly affects brand equity

Hypothesis $4:$ brand credibility significantly mediates the effect of endorser credibility on brand equity

Hypothesis 5 : Geographic significantly moderates the effect of endorser credibility on brand credibility

Hypothesis 6: Geographic significantly moderates the effect of endorser credibility on brand equity

\section{RESEARCH METHOD}

\section{Location and Research Object}

The location of this research was conducted in Banda Aceh and Sabang on consumers who had used Wardah cosmetic products. The objects in this study were the Endorser Credibility as an independent variable, Brand Equity as a dependent variable, Brand Credibility as a mediating variable, and Geographic as a moderating variable.

\section{Population and Sample}




\section{International Journal of Business Management and Economic Review}

Vol. 4, No. 04; 2021

ISSN: 2581-4664

The population in this study was all people who had used Wardah Cosmetics. Because of the relatively large population, sampling was needed. The number of customers was not known with certainty, so this study used Non-Probability Sampling, a sampling technique that does not provide the same opportunity for each element or member of the population selected to become a sample. The sampling technique used was purposive sampling with the number of respondents in this study amounting to 200 people according to (F. Hair Jr, Sarstedt, Hopkins, \& G. Kuppelwieser, 2014). Because in this study using the geographical variable as moderating variable, the number of a sample taken was divided into two, namely 100 respondents for the Banda Aceh area and 100 respondents for the Sabang area.

\section{Data collection technique}

The data were collected using documentation and a questionnaire. Documentation is a method used to obtain supporting data by analyzing documented information in the form of books, notes, or documents, and a questionnaire is a paper that contains some written questions that are used to obtain information from the respondent in the sense of a report about his personality, or things he knows (Arikunto, 2014). In this study, the questionnaire was distributed to wardah's consumers in Banda Aceh and Sabang.

Table 1. Research Scale

\begin{tabular}{|l|l|l|}
\hline NO & Pertanyaan & Skor \\
\hline 1 & Strongly agree & 5 \\
\hline 2 & Agree & 4 \\
\hline 3 & Less Agree & 3 \\
\hline 4 & Disagree & 2 \\
\hline 5 & Strongly disagree & 1 \\
\hline
\end{tabular}

\section{Operational Research Variable}

The research variables, their dimensions, and indicators have been formulated and stated as follows.

1. Brand Equity

1. Brand Awareness

a. I know wardah cosmetics

b. I can understand wardah cosmetics

c. Some cosmetics from Wardah appeared in my mind quickly

d. It is very possible that wardah cosmetics can offer the best prices

e. I believe Wardah is one of the responsible cosmetic product manufacturers

2. Quality Perception

a. It is very likely that wardah cosmetics have high-quality

b. It is very likely that wardah cosmetics have consistent quality

c. The possibility of wardah cosmetics offers superior features

d. I feel loyal to Wardah when considering cosmetics repurchase

e. It is likely that Wardah will be my first choice when considering purchasing cosmetics

2. Brand Credibility 
International Journal of Business Management and Economic Review

Vol. 4, No. 04; 2021

ISSN: 2581-4664

a. The Wardah brand reminds me of someone who is competent and knows what he is doing

b. Wardah brand has the ability to realize what is promised

c. Claim wardah products can be trusted

d. Wardah has a name that can be trusted

e. Wardah never released a product that disappointed me

3. Endorser Credibility

\section{Attraction}

a. Celebrities used by Wardah as endorser celebrities are very interesting

b. Celebrities used by Wardah as endorser celebrities are very elite

c. Celebrities used by Wardah as endorser celebrities are very pretty

d. Celebrities used by Wardah as endorser celebrities are very elegant

e. Celebrities used by Wardah as endorser celebrities are very sexy

2. Trustworthiness

a. Celebrities used by Wardah as endorser celebrities can be relied on

b. Celebrities used by Wardah as endorser celebrities are very honest

c. Celebrities used by Wardah as endorser celebrities do not need to doubt their reliability

d. Celebrities used by Wardah as sincere endorser celebrities

e. Celebrities used by Wardah as endorser celebrities can be trusted in delivering messages in Wardah.

\section{Data Analysis Method}

This research model was tested using Structural Equation Model (SEM). The research model also was tested the direct and indirect influences into 3 models, namely the combined model between the Banda Aceh and Sabang areas, the Banda Aceh model, and the Sabang model, where the results can be used as a comparative analysis. The moderation test was tested to the combined model.

\section{RESULT AND DISCUSSION}

\section{Direct Hypothesis And Mediation Testing}

The research model was tested into 3 models, namely the combined model between the Banda Aceh and Sabang areas, the Banda Aceh model, and the Sabang model. The full test result of the Banda Aceh region is explained in the picture below.

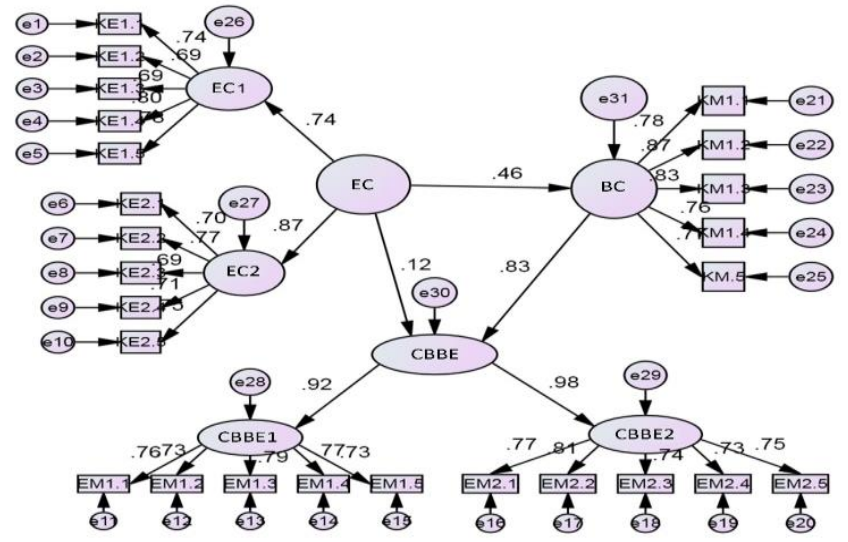


International Journal of Business Management and Economic Review

Vol. 4, No. 04; 2021

ISSN: 2581-4664

Figure 2. Research Model of Banda Aceh Area

Based on the test results as shown in the picture above shows the full model test for the Banda Aceh area. The Endorser Credibility directly influences the brand Credibility with a coefficient value of 0.46. The Endorser Credibility directly influences the Brand Equity with a coefficient of 0.12 and the Brand Credibility significantly influences the Brand Equity with a coefficient value of 0.83 .

While the full test result of the Sabang city is described in the picture below.

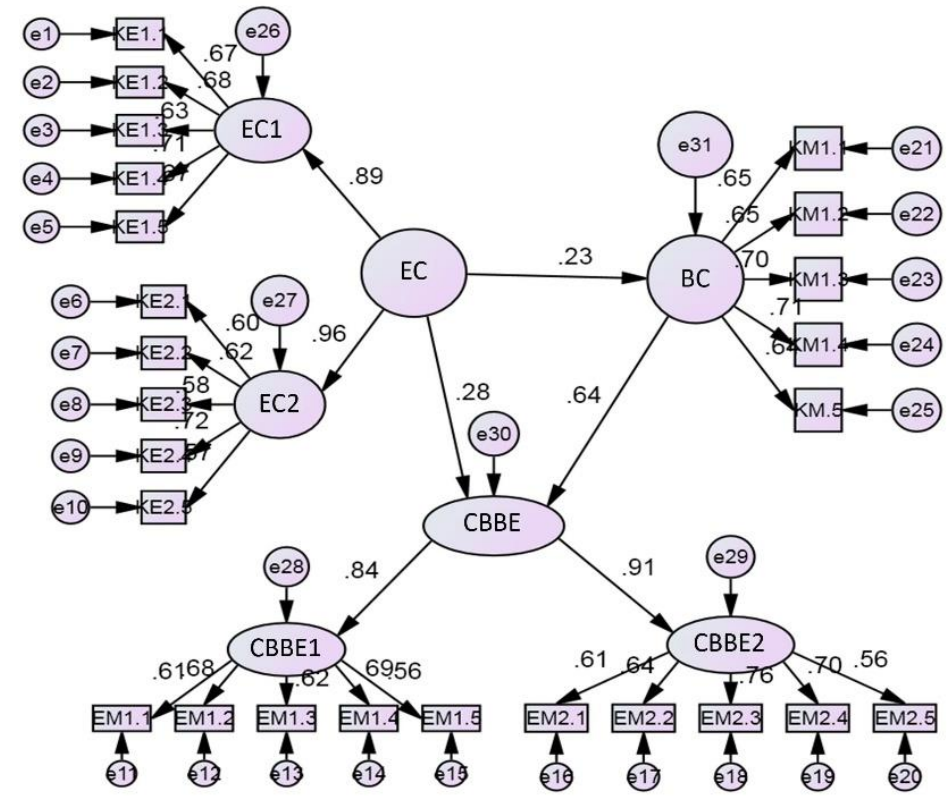

Figure 3. Research Model of Sabang Area

The result test for the Sabang area as shown in the picture above shows that the Endorser Credibility directly influences the Brand Credibility results the coefficient value of 0.23 , which means that it is lower than the Banda Aceh area, the Endorser Credibility directly influences the Brand Equity results a coefficient value of 0.28 , which means it is higher than the Banda Aceh area, and also the Brand Credibility affects directly to Brand Equity with a coefficient value of 0.64 which means lower compared to the Banda Aceh city.

Besides, the full model test result of general respondents (Banda Aceh and Sabang combined respondents) is explained with the picture below. 
International Journal of Business Management and Economic Review

Vol. 4, No. 04; 2021

ISSN: 2581-4664

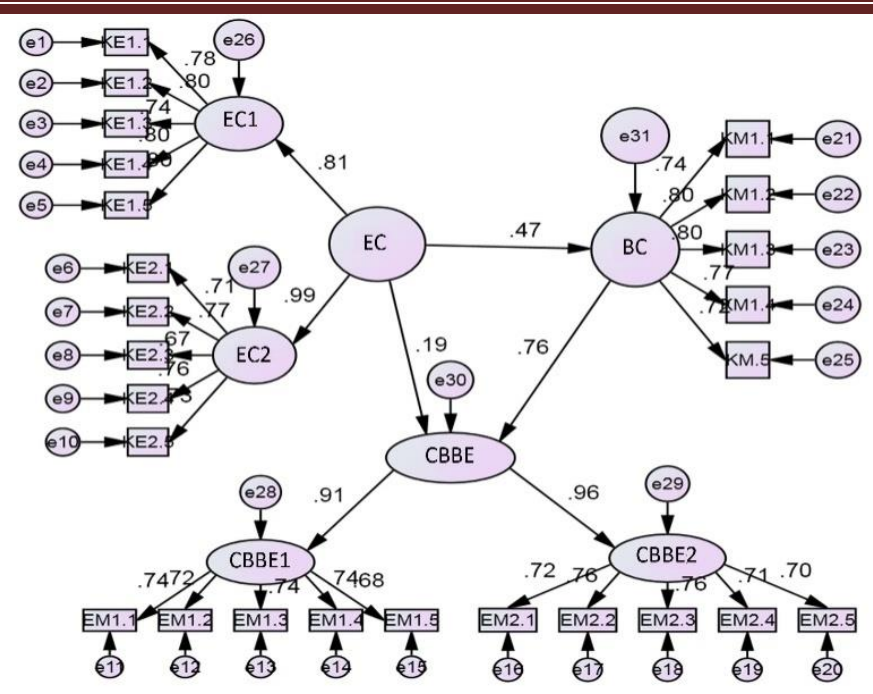

Figure 4. Research Model Combined of Banda Aceh and Sabang

This third model is the general model or a combination model between the Banda Aceh city and the Sabang city as shown in the picture above. For the Endorser Credibility directly influences the Brand Credibility results the coefficient value of 0.47 , which means that in these two combined cities full model, the coefficient value is higher than each full model.For the effect of Endorser Credibility on the Brand Credibility results the coefficient value of 0.19 which means that in these two combined cities full model the value is higher compared to the Banda Aceh area but the value is lower compared to the Sabang area, and otherwise for the Brand Credibility of Brand Equity results the coefficient value of 0.76 which means that in these two combined cities full model the coefficient value is higher compared to the Sabang area and lower compared to the Banda Aceh city. Furthermore, with all direct effects proven to have a significant effect, the brand credibility variable can be ascertained to function as a partial mediator in the all models.

Moderation Hypothesis Testing (Combined Model)

Table 2. Full Model

\begin{tabular}{|l|ccccccc|}
\hline Model & DF & CMIN & P & $\begin{array}{l}\text { NFI } \\
\text { Delta-1 }\end{array}$ & $\begin{array}{l}\text { IFI } \\
\text { Delta-2 }\end{array}$ & $\begin{array}{l}\text { RFI } \\
\text { rho-1 }\end{array}$ & $\begin{array}{l}\text { TLI } \\
\text { rho2 }\end{array}$ \\
\hline Structural weights & 46 & 28.545 & $\mathbf{9 8 0}$ & .005 & .006 & -.005 & -.006 \\
\hline
\end{tabular}

Sumber: AMOS 2020

Because $\mathrm{P}=0.980>0.05$, it reveals that there is no significant difference between respondents in Banda Aceh and Sabang in responding to the marketing policy implemented by Wardah Cosmetic.

Table 3. Geographical moderation influences Endorser Credibility on Brand Credibility

\begin{tabular}{|l|lllllll|}
\hline Model & \multirow{2}{*}{ DF } & \multirow{2}{*}{ CMIN } & P & $\begin{array}{l}\text { NFI } \\
\text { Delta-1 }\end{array}$ & $\begin{array}{l}\text { IFI } \\
\text { Delta-2 }\end{array}$ & $\begin{array}{l}\text { RFI } \\
\text { rho-1 }\end{array}$ & $\begin{array}{l}\text { TLI } \\
\text { rho2 }\end{array}$ \\
\hline
\end{tabular}


International Journal of Business Management and Economic Review

Vol. 4, No. 04; 2021

ISSN: 2581-4664

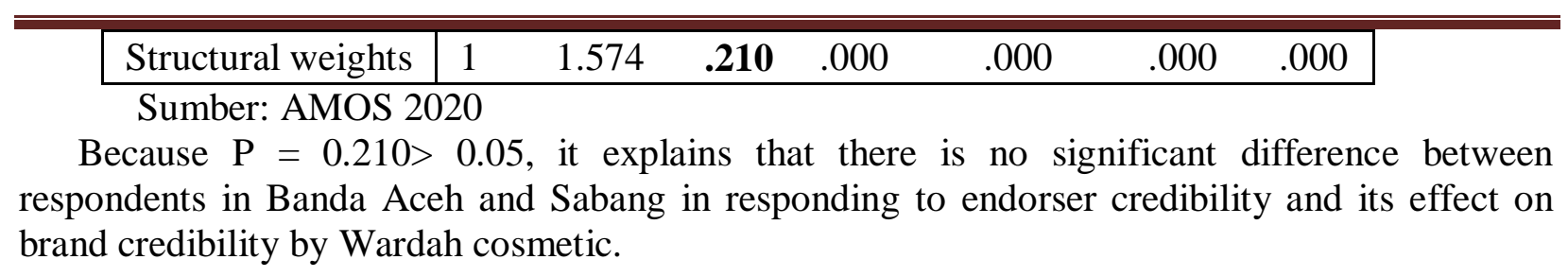

Table 4. Geographic moderation influences Endorser Credibility on Brand Equity

\begin{tabular}{|l|lllllll|}
\hline Model & DF & CMIN & P & $\begin{array}{l}\text { NFI } \\
\text { Delta-1 }\end{array}$ & $\begin{array}{l}\text { IFI } \\
\text { Delta-2 }\end{array}$ & $\begin{array}{l}\text { RFI } \\
\text { rho-1 }\end{array}$ & $\begin{array}{l}\text { TLI } \\
\text { rho2 }\end{array}$ \\
\hline Structural weights & 1 & 2.411 & $\mathbf{. 1 2 0}$ & .000 & .000 & .000 & .000 \\
\hline
\end{tabular}

Sumber: AMOS 2020

Because $\mathrm{P}=0.120>0.05$, it can be said that there is no significant difference between respondents in Banda Aceh and Sabang in responding to endorser credibility and its effect on brand equity carried out by Wardah Cosmetics.

\section{CONCLUSION}

The results of the research model testing with Wardah Products in Banda Aceh and Sabang market area show that the 3 models for direct and mediation hypothesis testing produced the same significant results, namely endorser credibility significantly affects brand credibility, endorser credibility significantly affects brand equity, brand credibility significantly affects brand equity, and brand credibility significantly mediates the effect of endorser credibility on brand equity. What distinguishes it is the coefficient of value, which can be used as a measure of comparison between the combined model, the Banda Aceh model, and the Sabang model. In the comparison of coefficient value between Banda Aceh and Sabang, it reveals that Banda Aceh's endorser credibility is more effective than Sabang's endorser credibility in affecting brand equity, and also Banda Aceh's brand credibility is more effective in affecting brand equity. But, Sabang's endorser credibility is more effective than Banda Aceh's endorser credibility in affecting brand equity. In the comparison between each full model of Banda Aceh, Sabang, and combined cities, the combined cities full model shows its endorser credibility is more effective in affecting the brand credibility compared to Banda Aceh and Sabang, Banda Aceh shows its brand credibility is more effective in affecting the brand equity, and Sabang shows its endorser credibility is more effective in affecting the brand credibility. Besides, In the moderation test of the combined model,it reveals that Geographic does not significantly moderate the effect of endorser credibility on brand credibility, and Geographic does not significantly moderate the effect of endorser credibility on brand equity. Geographical does not moderate in the research model means the presence of this variable does not affect the research model.

The findings prove that the designed model can be used to increase Wardah Cosmetic's brand equity for Banda Aceh and Sabang cities, without taking geographic variable into account. This means that strategies to increase brand equity for the Banda Aceh and Sabang geographic areas will tend to be the same. The findings also prove that Banda Aceh and Sabang have their respective advantages and achievements in treating each variable in the research model, so that they can exemplify each other and combine their future strategies. Further researchers are expected to be able to develop this model by expanding the research area, and by adding 
International Journal of Business Management and Economic Review

Vol. 4, No. 04; 2021

ISSN: 2581-4664

variables such as customer relationship management and brand awareness.

\section{REFERENCES}

Arikunto, S. (2014). Prosedur Penelitian suatu Pendekatan Praktik. Jakarta: Renika Cipta.

Baek, T. H., \& King, K. W. (2011). Exploring the Consequences of Brand Credibility in Services. Journal of Services Marketing, 25(4), 260-272. https://doi.org/https://doi.org/10.1108/08876041111143096

Chen, C.-F., \& Chang, Y.-Y. (2008). Airline brand equity, brand preference, and purchase intentions-The moderating effects of switching costs. Journal of Air Transport Management, 14(1), 40-42. https://doi.org/https://doi.org/10.1016/j.jairtraman.2007.11.003

Erdem, Tulin, \& Swait, J. (2004). Brand credibility brand consideration and choice. Journal of Consumer Research, 31(1), 191-198. https://doi.org/https://doi.org/10.1086/383434

Erdem, Tülin, Swait, J., \& Louviere, J. (2002). The impact of brand credibility on consumer price sensitivity. International Journal of Research in Marketing, 19(1), 1-19. https://doi.org/https://doi.org/10.1016/S0167-8116(01)00048-9

F. Hair Jr, J., Sarstedt, M., Hopkins, L., \& G. Kuppelwieser, V. (2014). Partial least squares structural equation modeling (PLS-SEM) An emerging tool in business research. European Business Review, 26(2), 106-121.

Kotler, P., \& Keller, K. L. (2009). Manajemen Pemasaran (12th ed.). Jakarta: PT. Indeks.

Kotler, P., \& Keller, K. L. (2018). Marketing Management, Global Edition (15th editi). Harlow, United Kingdom: Pearson.

Mukherjee, D. (2009). Impact of Celebrity Endorsements on Brand Image. Social Science Research Network Electronic Paper Collection, 1-35. https://doi.org/http://dx.doi.org/10.2139/ssrn.1444814

Roll, M. (2006). Asian Brand Strategy "How Asia Builds Strong Brands." https://doi.org/10.1057/9780230513068

Sheeraz, M., Iqbal, N., \& Ahmad, N. (2012). Impact of Brand Credibility and Consumer Values on Consumer Purchase Intentions in Pakistan. International Journal of Academic Research in Business and Social Sciences, 2(8), 1-10.

Shimp, T. A. (2013). Advertising, Promotion, adn Other Aspect of Integrated Marketing Communivations. In Journal of Chemical Information and Modeling (7th Editio, Vol. 53). https://doi.org/10.1017/CBO9781107415324.004 